\title{
A large-scale analysis study on the clinical and viral characteristics of hepatitis $B$ infection with concurrence of hepatitis B surface or $\mathbf{E}$ antigens and their corresponding antibodies
}

\author{
Y. Xiang*, P. Chen*, J.R Xia and L.P. Zhang \\ Department of Laboratory Medicine, \\ The First Affiliated Hospital of Chongqing Medical University, \\ Yuzhong District, Chongqing, China \\ *These authors contributed equally to this study. \\ Corresponding author: L.P. Zhang \\ E-mail: 8051226@163.com
}

Genet. Mol. Res. 16 (1): gmr16019102

Received August 29, 2016

Accepted December 6, 2016

Published February 23, 2017

DOI http://dx.doi.org/10.4238/gmr16019102

Copyright (C) 2017 The Authors. This is an open-access article distributed under the terms of the Creative Commons Attribution ShareAlike (CC BY-SA) 4.0 License.

\begin{abstract}
Concurrent detection of hepatitis B surface antigen (HBsAg) and anti-HBs antibody or hepatitis B surface E antigen $(\mathrm{HBe} A g)$ and anti-HBe antibody in patients with chronic hepatitis B (CHB) infection is well established. However, the clinical implications of these proteins remain largely unknown. In this study, demographic, clinical, and laboratory data from 124,865 patients with chronic CHB infection were analyzed. Viral genotypes were determined by nested polymerase chain reaction. A chemiluminescent assay was applied to measure $\mathrm{HBsAg}, \mathrm{HBsAb}, \mathrm{HBeAg}, \mathrm{HBeAb}$, and $\mathrm{HBcAb}$ in sera. Among 124,865 patients with CHB infection, $324(0.3 \%)$ were concurrently positive for HBsAg and anti-HBs, and $206(0.2 \%)$ were concurrently positive for $\mathrm{HBeAg}$ and anti-HBe. The $\mathrm{HBeAg}+/$ anti-HBe+ group was composed of younger patients $(\mathrm{P}<0.05)$. Subgenotype $\mathrm{B} 2$ was prevalent in $\mathrm{HBV}$ patients concurrently positive for $\mathrm{HBeAg}$ and anti-HBe, while
\end{abstract}

Genetics and Molecular Research 16 (1): gmr16019102 
HBV patients positive for both HBsAg and anti-HBs exhibited the $\mathrm{C} 2$ subgenotype. Among 530 concurrent patients, 126 (39\%) $\mathrm{HBsAg}+/$ anti-HBs+ patients were in the low-replication phase, and $62(19 \%)$ were in the reactivation phase; $87(42 \%) \mathrm{HBeAg}+/$ anti-HBe+, and 19 (6\%) $\mathrm{HBsAg}+/$ anti-HBs + patients were in the immune clearance phase. In this large-scale analysis, the clinical and viral characteristics of HBV infections with concurrent $\mathrm{HBs} \mathrm{Ag} /$ antibody or $\mathrm{HBe} \mathrm{Ag} /$ antibody presentations have been examined, and the results may contribute to the diagnosis and treatment of CHB patients.

Key words: Hepatitis B surface antigen; Chronic hepatitis B; Hepatitis B virus; Hepatitis E virus

\section{INTRODUCTION}

The prevalence of Hepatitis B virus (HBV) and Hepatitis E virus (HEV) is high in China. However, the sero-prevalence of HEV shows an unbalanced distribution among different geographical locations and economic development levels (Jia et al., 2014). HBV infection is the primary cause of chronic hepatitis B (CHB) infection, cirrhosis, and hepatocellular carcinoma (HCC) (Kao and Chen, 2002). Most cases of HCC are associated with cirrhosis, as well as chronic hepatitis B or C viral infections (El-Serag, 2012). CHB infection is considered endemic in China with a carrier rate of $8-20 \%$ in the general population. Approximately 130 million people are carriers for the hepatitis B surface antigen (HBsAg) (Luo et al., 1996). Anti-HBs antibodies are the major protective components of vaccine-induced immunity. The majority of people with "resolved" HBV infections harbor the virus intra-hepatically. However, viral replication is controlled by cytotoxic T lymphocytes, and spread is blocked by neutralizing antiHBs antibodies in the host system. In view of their important protective roles, the presence of anti-HBs antibodies in $\mathrm{HBsAg}$-positive patients with CHB infection is extremely puzzling.

Hepatitis B surface $\mathrm{E}$ antigen $(\mathrm{HBe} \mathrm{Ag})$ is an antigen that can be found between the nucleocapsid core and the lipid envelope. Its correlation with HBV replication is commonly used as a serological marker of CHB infection. When HBeAg disappears, anti-HBe antibodies become detectable. However, in clinical practice, some $\mathrm{CHB}$ patients show concurrent $\mathrm{HBeAg}$ and anti-Hbe positivity (Liaw, 2009; McMahon, 2009). A previous study has shown that 169 chronic patients $(169 / 1624,10.4 \%)$ had concurrent HBeAg and anti-HBe positivity, which was associated with intermediate age and HBV-DNA load, higher alanine aminotransferase level, and more pronounced liver damage as compared with HBeAg-positive or anti-HBe-positive patients alone (Wang et al., 2011).

The aim of this study was to investigate the clinical and viral characteristics of HBV, and to explore the potential mechanisms involved in the concurrent presence of $\mathrm{HBeAg} /$ anti$\mathrm{HBe}$ or HBsAg/anti-HBs in CHB infections.

\section{MATERIAL AND METHODS}

\section{Patients}

A total of 124,865 patients with CHB infection were recruited from the First Affiliated

Genetics and Molecular Research 16 (1): gmr16019102 
Hospital of Chongqing Medical University (Chongqing, China). All subjects provided written informed consent prior to being enrolled in this study. All patients fulðlled the following criteria: 1) diagnosed with CHB infection according to the Chinese consensus criteria (Chinese Society of Hepatology, Chinese Medical Association, Chinese Society of Infectious Diseases, Chinese Medical Association, 2007), and 2) persistent or intermittent elevation of serum alanine aminotransferase (ALT) levels within 12 months before enrollment. All patients with former anti-virus therapy, co-infection with hepatitis C, hepatitis D, or HIV were excluded from the study. The study protocol was approved and carried out in accordance with the guidelines of the Ethics Committee of Chongqing Medical University.

To examine the interplay between the virus and host, $\mathrm{CHB}$ patients were grouped according to the four dynamic phases of CHB infection (Liaw, 2009; McMahon, 2009). CHB patients with positive $\mathrm{HBeAg}, \mathrm{HBV}$ DNA $>2 \times 10^{7}$, and normal ALT level were classified into the immune tolerance (IT) group; patients with positive HBeAg, HBV DNA $>2 \times 10^{4}$, and elevated ALT levels were classified into the immune clearance (IC) group; patients with negative $\mathrm{HBeAg}, \mathrm{HBV}$ DNA $<2 \times 10^{3}$, and normal ALT levels were included in the low replicative (LR) group; patients with negative $\mathrm{HBeAg}$, HBV DNA $>2 \times 10^{3}$, and elevated ALT levels were included in the reactivation (RE) group.

\section{Detection of $\mathrm{HBsAg}$, anti-HBs, $\mathrm{HBeAg}$ and anti-HBe}

Chemiluminescent microparticle immune assays (Abbott Diagnostics, Irving, TX, USA) were employed to quantify serum levels of $\mathrm{HBsAg}$, anti-HBs, $\mathrm{HBeAg}$, and anti-HBe. A serum HBsAg level of $>0.05 \mathrm{IU} / \mathrm{mL}$, anti-HBs $>10 \mathrm{mIU} / \mathrm{mL}, \mathrm{HBeAg}$ titer $>1.0$ signal to cutoff ratio $(\mathrm{S} / \mathrm{CO})$, an anti-HBe titer $<1.0 \mathrm{~S} / \mathrm{CO}$ was regarded as positive. The limitations of the chemiluminescent assay used for antibody/antigen detection was as follows: 1) for HBsAg, precision for reactive specimens $(\mathrm{S} / \mathrm{CO} \geq 1.000)$ was $\leq 10 \%$, total specificity and total sensitivity were 99.87 and $99.52 \%$, respectively; 2 ) for anti-HBs, precision for reactive specimens (S/CO $\geq 1.000$ ) was $\leq 10 \%$, total specificity and total sensitivity were 99.67 and $97.54 \%$, respectively; 3 ) for $\mathrm{HBeAg}$, precision for reactive specimens ( $\mathrm{S} / \mathrm{CO} \geq 1.000)$ was $\leq 10 \%$. The specificity for random blood donor and hospitalized patient specimens were $\geq 99.5$ and $>99.0 \%$, respectively. The sensitivity was $\geq 99.5 \%$; 4) for anti-HBe, precision for reactive specimens $(\mathrm{S} / \mathrm{CO} \geq 1.000)$ was $\leq 10 \%$. The specificity for random blood donor and hospitalized patient specimens were $\geq$ 99.5 and $>99.0 \%$, respectively. The sensitivity was $\geq 99.5 \%$.

\section{HBV DNA extraction, quantitation, direct sequencing, and genotyping}

HBV DNA loads were quantified by real-time polymerase chain reaction (PCR). DNA was extracted from $100 \mu \mathrm{L}$ serum using the QIAamp DNA Mini kit (Qiagen Inc., Hilden, Germany) according to manufacturer's recommendations. The lower detection limit of this assay was $10^{3} \mathrm{IU}$ of HBV DNA $/ \mathrm{mL}$.

Molecular genotyping for genotypes A-D and subgenotypes B1, B2, C1, and C2 were performed according to the nested PCR methods established by Jin et al. (2008).

\section{Routine tests}

The serum levels of ALT and AST were detected using an automatic biochemistry

Genetics and Molecular Research 16 (1): gmr16019102 
analyzer (Roche Diagnostics, Rotkreuz, Switzerland). Liver histology was independently assessed by two pathologists according to the Scheuer scoring system.

\section{Statistical analysis}

Continuous variables are presented as means $\pm \mathrm{SD}$, while categorical variables are presented as frequency (percentage). For between-group comparisons, Student's $t$-test was used for continuous variables, and the chi-square test was used for categorical data. Comparisons between different groups were carried out using analysis of variance. All $\mathrm{P}$ values were based on a two-sided test of statistical significance. Significance was accepted at $\mathrm{P}<0.05$. All analyses were performed using the SPSS software for Windows, version 13.0 (IBM-SPSS, Inc., Chicago, IL, USA).

\section{RESULTS}

\section{Demographic and clinical characteristics of CHB patients}

A total of 124,865 CHB patients fuldlled the study criteria, including 324 patients $(0.3 \%)$ concurrently positive for HBsAg and anti-HBs, and 206 patients $(0.2 \%)$ concurrently positive for $\mathrm{HBeAg}$ and anti-HBe. The demographic, clinical, and serological characteristics of the study participants are shown in Table 1. Patients in the $\mathrm{HBeAg}+/$ anti-HBe + group were found to be significantly younger as compared to the other groups $(\mathrm{P}<0.05)$. Subgenotype B2 $(137,66.7 \%)$ was prevalent in CHB patients concurrently positive for HBeAg and anti$\mathrm{HBe}$, and subgenotype C2 $(108,33.3 \%)$ was predominantly found in chronic hepatitis B patients who were positive for both HBsAg and anti-HBs $(\mathrm{P}<0.05)$. There were no significant difference in the sex, ALT, AST, and HBV DNA level between the HBsAg+/anti-HBs+ and the $\mathrm{HBeAg}+/$ anti-HBe+ groups.

Table 1. Demographic and clinical characteristics of CHB patients concurrently positive for HBsAg+/anti$\mathrm{HBs}+$ and $\mathrm{HBeAg}+/$ anti-HBe+.

\begin{tabular}{|c|c|c|c|c|}
\hline \multirow{2}{*}{\multicolumn{2}{|c|}{ Total N (\%) }} & $\mathrm{HBsAg}+/$ anti-HBs $+^{+}$ & $\mathrm{HBeAg}+/$ anti-HBe+ & $P$ value \\
\hline & & $324(0.3 \%)$ & $206(0.2 \%)$ & \\
\hline \multicolumn{2}{|l|}{ Age (year) } & $46.0 \pm 17.0$ & $36.0 \pm 12.5$ & $\mathrm{P}<0.05$ \\
\hline \multicolumn{2}{|c|}{ Male, N (\%) } & $170(52.5 \%)$ & $136(66.0 \%)$ & \multirow[t]{2}{*}{$\mathrm{P}<0.05$} \\
\hline \multicolumn{2}{|c|}{ Female, N (\%) } & $154(47.5 \%)$ & $70(44.0 \%)$ & \\
\hline \multicolumn{2}{|l|}{$\mathrm{ALT}, \mathrm{U} / \mathrm{L}$} & $84.3 \pm 296.7$ & $123.3 \pm 134.9$ & $\mathrm{P}>0.05$ \\
\hline \multicolumn{2}{|l|}{ AST,U/L } & $67.4 \pm 153.4$ & $64.9 \pm 55.5$ & $\mathrm{P}>0.05$ \\
\hline \multicolumn{2}{|c|}{ HBV DNA, (copies/mL) } & $4.7 \times 10^{6} \pm 2.5 \times 10^{7}$ & $1.0 \times 10^{7} \pm 2.1 \times 10^{7}$ & $\mathrm{P}>0.05$ \\
\hline \multirow[t]{3}{*}{ Genotypes } & $\mathrm{B} 2, \mathrm{~N}(\%)$ & $27(8.3 \%)$ & $137(66.7 \%)$ & \multirow[t]{3}{*}{$\mathrm{P}<0.05$} \\
\hline & $\mathrm{C} 2, \mathrm{~N}(\%)$ & $108(33.3 \%)$ & $17(8.3 \%)$ & \\
\hline & Undetected, N (\%) & $189(58.4 \%)$ & $52(25.0 \%)$ & \\
\hline
\end{tabular}

\section{Natural courses of CHB patients}

Of the 530 concurrent patients, $126(39 \%)$ with double positivity for HBsAg and antiHBs were in the low-replication phase of the disease, and $62(19 \%)$ were in the reactivation phase. Out of the 87 patients (42\%) positive for HBeAg and anti-HBe, $19(6 \%)$ were in the immune clearance phase. None of the concurrent patients were in the IT (immune tolerance) group. All $\mathrm{HBeAg}+/$ anti-HBe + and $\mathrm{HBsAg}+/$ anti-HBs + patients were in the immune clearance

Genetics and Molecular Research 16 (1): gmr16019102 
phase. Of the 206 patients positive for both $\mathrm{HBeAg}$ and anti-HBe, most were categorized into the IC group. Of the 324 patients with HBsAg and anti-HBs positivity, most were in the LR phase of the CHB infection (Table 2).

Table 2. Distribution ofnatural disease courses in patients with CHB infection.

\begin{tabular}{l|c|c|c|c}
\hline & $\begin{array}{c}\text { IT group } \\
\mathrm{N}(\%)\end{array}$ & $\begin{array}{c}\text { IC group } \\
\mathrm{N}(\%)\end{array}$ & $\begin{array}{c}\text { LR group } \\
\mathrm{N}(\%)\end{array}$ & $\begin{array}{c}\text { RE group } \\
\mathrm{N}(\%)\end{array}$ \\
\hline $\mathrm{HBeAg}+$ anti-HBe+ $(\mathrm{N}=206)$ & 0 & $87(42 \%)$ & 0 & 0 \\
\hline $\mathrm{HBs}+/$ anti-HBs+ $(\mathrm{N}=324)$ & 0 & $19(6 \%)$ & $126(39 \%)$ & $62(19 \%)$ \\
\hline
\end{tabular}

$\mathrm{IT}=$ immune tolerance; $\mathrm{IC}=$ immune clearance; $\mathrm{LR}=$ low replicative; $\mathrm{RE}=$ reactivation.

\section{DISCUSSION}

The coexistence of HBsAg and anti-HBs in patients with $\mathrm{CHB}$ infection has been reported (Lada et al., 2006; Huang et al., 2010). Theoretically, the concurrence of HBsAg and anti-HBs occurs regularly during the recovery period of acute HBV infections. However, there may be other factors that can lead to coexistence of HBsAgs and anti-HBs. This may include $\mathrm{CHB}$ carriage with ineffective anti-HBs responses, breakthrough of $\mathrm{HBV}$ in vaccinated individuals, and HBV reactivation in immune patients who underwent immunosuppression therapies (Yu et al., 2005). Of the 124,865 CHB patients in this study, $324(0.3 \%)$ were concurrently positive for HBsAg and anti-HBs, of whom $62(19 \%)$ were in the reactivation phase of the disease. Further genotyping assays demonstrated that subgenotype C2 (108, $33.3 \%$ ) was predominantly expressed in CHB patients positive for both HBsAg and anti-HBs. It has been reported that genotype $\mathrm{C}$ is the predominant HBV strains in Chinese HBsAg+/antiHBs ${ }^{+}$patients (Liu et al., 2012). Moreover, the presence of genotype $\mathrm{C}$ has been suggested as an independent predictive factor of elevated ALT, which corresponds to liver damage and HBV reactivation (Chu and Liaw, 2007a). Some studies have also demonstrated that Chinese patients with genotype C were at a greater risk for HCC (Chan et al., 2004; Yu et al., 2005). It has been suggested that the coexistence of HBsAg and anti-HBs may be a mixed infection response and a monoclonal response to a single epitope (Margeridon et al., 2005). Other studies suggested that amino acid substitutions may decrease or abolish the binding of antiHBs to HBsAg, leading to immune escape (Mesenas et al., 2002; Mathet et al., 2003; Lada et al., 2006). This was supported by the observation that coexistence of HBsAg and anti-HBs is correlated with increased nucleotide variability in key areas of the HBV genome (Chen et al., 2011). Current studies also indicated that the serological profile of these patients showed minimal HBV replication and active CHB despite the presence of anti-HBs at a protective level (Colson et al., 2007; Liu et al., 2012). Therefore, we did not investigate the relationship between the $\mathrm{HBsAg}+/$ anti-HBs + serological profiles and HBV replication in this study.

$\mathrm{HBeAg}$ positivity can be observed in most patients during the immune-tolerance phase. Transition of the disease to the immune active phase occurs with loss of HBeAgs and the development of anti-HBes in a step called HBeAg seroconversion (McMahon, 2009). Among the 124,865 CHB patients included in this study, $206(0.2 \%)$ were concurrently positive for $\mathrm{HBeAg}$ and anti-HBe. Patients in the $\mathrm{HBeAg}+/$ anti-HBe+ group were younger as compared to those in the other groups $(\mathrm{P}<0.05)$. Additionally, subgenotype B2 $(137,66.7 \%)$ was prevalent in $\mathrm{CHB}$ patients concurrently positive for $\mathrm{HBeAg}$ and anti-HBe. This genotype has previously been shown to have early and frequent $\mathrm{HBeAg}$ seroconversion with less progressive liver disease as compared to genotype C (Chu and Liaw, 2005).

Genetics and Molecular Research 16 (1): gmr16019102 
The first immune-tolerance phase is characterized by exceedingly high HBV DNA levels and the presence of HBeAgs. At this time, there is low hepatitis activity, as reflected by normal serum transaminase level despite active HBV replication (Yim and Lok, 2006). When the second immune clearance phase ensues, the liver cells suffer continuous damage due to immune-mediated cytotoxic responses (Liaw et al., 1985; Sprengers et al., 2006). However, following immune attacks, HBV replication is impermanently suppressed. The third low-replication phase is characterized by the absence of HBeAgs, the presence of antiHBes, persistently normal serum transaminase levels, and low or undetectable serum HBV DNA. HBV could also replicate in the absence of $\mathrm{HBeAg}$, hence the fourth reactivation phase could be observed, which may occur spontaneously (Chu and Liaw, 2007b) or as a result of immunosuppression (Calabrese et al., 2006). In this study, of the 206 patients positive for both $\mathrm{HBeAg}$ and anti-HBe, the IC group (42\%) was prevalent during the natural phases of CHB. Of the 324 patients positive for both $\mathrm{HBsAg}$ and anti-HBs, they were predominantly categorized (39\%) into the LR group. The decreased affinity between $\mathrm{HBeAg}$ and anti-HBe could explain the concurrent patterns. Furthermore, the concurrent patients may also be undergoing $\mathrm{HBeAg}$ and anti-HBe seroconversion.

A limitation to this study was the small number of CHB patients with concurrence of HBs and HBe antigens with their corresponding antibodies. Further large-scale, multi-center studies are needed to clarify the clinical implications of these serological patterns (HBsAg and anti-HBs positivity, or HBsAg and anti-HBs positivity), including specific $\mathrm{T}$ cell immune responses, the efficacy of antiviral agents, and the clinical course of the disease.

\section{Conflicts of interest}

The authors declare no conflict of interest.

\section{ACKNOWLEDGMENTS}

Research supported by the Medical Research Project of Chongqing Health Bureau in 2013 (grant \#2013-2-022) and the Science and Technology Research Projects of Chongqing Education Committee in 2016 (grant \#KJ1600230).

\section{REFERENCES}

Calabrese LH, Zein NN and Vassilopoulos D (2006). Hepatitis B virus (HBV) reactivation with immunosuppressive therapy in rheumatic diseases: assessment and preventive strategies. Ann. Rheum. Dis. 65: 983-989. http://dx.doi. org/10.1136/ard.2005.043257

Chan HL, Hui AY, Wong ML, Tse AM, et al. (2004). Genotype C hepatitis B virus infection is associated with an increased risk of hepatocellular carcinoma. Gut 53: 1494-1498. http://dx.doi.org/10.1136/gut.2003.033324

Chen Y, Qian F, Yuan Q, Li X, et al. (2011). Mutations in hepatitis B virus DNA from patients with coexisting HBsAg and anti-HBs. J. Clin. Virol. 52: 198-203. http://dx.doi.org/10.1016/j.jev.2011.07.011

Chinese Society of Hepatology, Chinese Medical Association; Chinese Society of Infectious Diseases, Chinese Medical Association (2007). Guideline on prevention and treatment of chronic hepatitis B in China (2005). Chin. Med. J. (Engl.) 120: 2159-2173.

Chu CM and Liaw YF (2005). Genotype C hepatitis B virus infection is associated with a higher risk of reactivation of hepatitis B and progression to cirrhosis than genotype B: a longitudinal study of hepatitis B e antigen-positive patients with normal aminotransferase levels at baseline. J. Hepatol. 43: 411-417. http://dx.doi.org/10.1016/j. 边ep.2005.03.018

Genetics and Molecular Research 16 (1): gmr16019102 
Chu CM and Liaw YF (2007a). Predictive factors for reactivation of hepatitis B following hepatitis B e antigen seroconversion in chronic hepatitis B. Gastroenterology 133: 1458-1465. http://dx.doi.org/10.1053/j.gastro.2007.08.039

Chu CM and Liaw YF (2007b). Spontaneous relapse of hepatitis in inactive HBsAg carriers. Hepatol. Int. 1: 311-315. http://dx.doi.org/10.1007/s12072-007-9002-9

Colson P, Borentain P, Motte A, Henry M, et al. (2007). Clinical and virological significance of the co-existence of HBsAg and anti-HBs antibodies in hepatitis B chronic carriers. Virology 367: 30-40. http://dx.doi.org/10.1016/j. virol.2007.05.012

El-Serag HB (2012). Epidemiology of viral hepatitis and hepatocellular carcinoma. Gastroenterology 142: 1264-1273.e1. http://dx.doi.org/10.1053/j.gastro.2011.12.061

Huang X, Qin Y, Zhang P, Tang G, et al. (2010). PreS deletion mutations of hepatitis B virus in chronically infected patients with simultaneous seropositivity for hepatitis-B surface antigen and anti-HBS antibodies. J. Med. Virol. 82: 23-31. http://dx.doi.org/10.1002/jmv.21669

Jin H, Wang J, Yan L, Nie JJ, et al. (2008). Establishment of a nested PCR to identify hepatitis B virus genotypes A-D and subgenotypes B1, B2, C1 and C2. Zhonghua Liu Xing Bing Xue Za Zhi 29: 1235-1239.

Jia Z, Yi Y, Liu J, Cao J, et al. (2014). Epidemiology of hepatitis E virus in China: results from the third national viral hepatitis prevalence survey, 2005-2006. PLoS One 9: e110837. http://dx.doi.org/10.1371/journal.pone.0110837

Kao JH and Chen DS (2002). Global control of hepatitis B virus infection. Lancet Infect. Dis. 2: 395-403. http://dx.doi. org/10.1016/S1473-3099(02)00315-8

Lada O, Benhamou Y, Poynard T and Thibault V (2006). Coexistence of hepatitis B surface antigen (HBs Ag) and antiHBs antibodies in chronic hepatitis B virus carriers: influence of "a" determinant variants. J. Virol. 80: 2968-2975. http://dx.doi.org/10.1128/JVI.80.6.2968-2975.2006

Liaw YF (2009). Natural history of chronic hepatitis B virus infection and long-term outcome under treatment. Liver Int. 29 (Suppl 1): 100-107. http://dx.doi.org/10.1111/j.1478-3231.2008.01941.x

Liaw YF, Yang SS, Chen TJ and Chu CM (1985). Acute exacerbation in hepatitis B e antigen positive chronic type B hepatitis. A clinicopathological study. J. Hepatol. 1: 227-233. http://dx.doi.org/10.1016/S0168-8278(85)80050-7

Liu W, Hu T, Wang X, Chen Y, et al. (2012). Coexistence of hepatitis B surface antigen and anti-HBs in Chinese chronic hepatitis $\mathrm{B}$ virus patients relating to genotype $\mathrm{C}$ and mutations in the $\mathrm{S}$ and $\mathrm{P}$ gene reverse transcriptase region. Arch. Virol. 157: 627-634. http://dx.doi.org/10.1007/s00705-011-1215-5

Luo K, Hou J and Liang C (1996). Hepatitis B virus infection and its genetic variations in China. Chin. J. Infect Dis. 14: 101-104.

Margeridon S, Lachaux A, Trepo C, Zoulim F, et al. (2005). A quasi-monoclonal anti-HBs response can lead to immune escape of 'wild-type' hepatitis B virus. J. Gen. Virol. 86: 1687-1693. http://dx.doi.org/10.1099/vir.0.80810-0

Mathet VL, Feld M, Espínola L, Sánchez DO, et al. (2003). Hepatitis B virus S gene mutants in a patient with chronic active hepatitis with circulating Anti-HBs antibodies. J. Med. Virol. 69: 18-26. http://dx.doi.org/10.1002/jmv.10267

McMahon BJ (2009). The natural history of chronic hepatitis B virus infection. Hepatology 49 (Suppl): S45-S55. http:// dx.doi.org/10.1002/hep. 22898

Mesenas SJ, Chow WC, Zhao Y, Lim GK, et al. (2002). Wild-type and 'a' epitope variants in chronic hepatitis B virus carriers positive for hepatitis B surface antigen and antibody. J. Gastroenterol. Hepatol. 17: 148-152. http://dx.doi. org/10.1046/j.1440-1746.2002.02627.x

Sprengers D, van der Molen RG, Kusters JG, Hansen B, et al. (2006). Different composition of intrahepatic lymphocytes in the immune-tolerance and immune-clearance phase of chronic hepatitis B. J. Med. Virol. 78: 561-568. http:// dx.doi.org/10.1002/jmv.20576

Wang J, Zhou B, Lai Q, Wang Y, et al. (2011). Clinical and virological characteristics of chronic hepatitis B with concurrent hepatitis B E antigen and antibody detection. J. Viral Hepat. 18: 646-652. http://dx.doi.org/10.1111/ j.1365-2893.2010.01345.x

Yim HJ and Lok AS (2006). Natural history of chronic hepatitis B virus infection: what we knew in 1981 and what we know in 2005. Hepatology 43 (Suppl 1): S173-S181. http://dx.doi.org/10.1002/hep.20956

Yu MW, Yeh SH, Chen PJ, Liaw YF, et al. (2005). Hepatitis B virus genotype and DNA level and hepatocellular carcinoma: a prospective study in men. J. Natl. Cancer Inst. 97: 265-272. http://dx.doi.org/10.1093/jnci/dji043

Genetics and Molecular Research 16 (1): gmr16019102 